\title{
Effects of pollution on oxidative stress in aquatic species: case of the fish Sarotherodon melanotheron in Bè Lagoon (Lomé)
}

\author{
Yendubé Touguelighan KANTATI ${ }^{1 *}$, Magloire Komlan KODJO ${ }^{1}$, Kissao GNANDI ${ }^{2}$, \\ Guillaume Koffivi KETOH ${ }^{3}$ and Messanvi GBEASSOR ${ }^{1}$
}

${ }^{1}$ Laboratoire de Physiologie/Pharmacologie, Faculté des Sciences, Université de Lomé, Togo.

${ }^{2}$ Laboratoire GTVD (Gestion, Traitement et Valorisation des Déchets), Faculté des Sciences, Université de Lomé, Togo.

${ }^{3}$ Unité de Recherche en Ecotoxicologie, Faculté des Sciences, Université de Lomé, Togo.

"Corresponding author, E-mail: yenduka02@yahoo.fr, P.O. Box: 1515 Lomé, Togo. Tel : (+228) 90180430 .

\begin{abstract}
This study aimed to assess heavy metals accumulation and oxidative stress biomarkers in the fish Sarotherodon melanotheron from a site receiving discharges from industrial and harbor activities (Bè Lagoon) and a reference or control site in Lake Togo, Togo. Atomic absorption spectrophotometry (AAS) targeting four heavy metals (lead, cadmium, copper and nickel) in the waters of Bè Lagoon showed levels of about $2.58 \pm$ $0.11 \mu \mathrm{g} / \mathrm{l}, 1.03 \pm 0.15 \mu \mathrm{g} / \mathrm{l}, 1.71 \pm 0.17 \mu \mathrm{g} / \mathrm{l}$ and $3.03 \pm 0.07 \mu \mathrm{g} / \mathrm{l}$ respectively for $\mathrm{Pb}, \mathrm{Cd}, \mathrm{Ni}, \mathrm{Cu}$. In water of the control site, only $\mathrm{Cu}$ and $\mathrm{Ni}$ were detected at lower levels: $1.54 \pm 0.22 \mu \mathrm{g} / \mathrm{l}$ for $\mathrm{Ni}$ and $0.89 \pm 0.18 \mu \mathrm{g} / \mathrm{l}$ for $\mathrm{Cu}$. Furthermore, in tissues (liver, muscle and gills) of the fish, the heavy metal contents are found in larger samples of the Bè Lagoon. Among the biological parameters (oxidative stress biomarkers), the catalase activity $(\mathrm{P}<0.0001$ in liver and $\mathrm{P}<0.005$ in gill) was found to be significantly higher in the fish collected from Bè lagoon when compared with control site. These changes in biomarkers response at the subcellular level therefore indicate an impact on the biology of the fishes living in Bè lagoon.

(C) 2013 International Formulae Group. All rights reserved.
\end{abstract}

Keywords: Bè lagoon, catalase activity, Lake Togo, MDA, pollution.

\section{INTRODUCTION}

Reactive oxygen species (ROS) such as hydroxyl radical $\left(\mathrm{OH}^{\cdot}\right)$, superoxide anion $\left(\mathrm{O}^{2-}\right)$, hydroperoxides $(\mathrm{ROOH})$, hydrogen peroxide $\left(\mathrm{H}_{2} \mathrm{O}_{2}\right)$, oxygen singlet $\left({ }^{1} \mathrm{O}_{2}\right)$ and peroxynitrite $\left(\mathrm{ONOO}^{-}\right)$are an unenviable part of aerobic life (Collén et al., 2003; Pereira et al., 2009). Their steady-state concentration is a balance between production and elimination providing certain steady-state ROS level. The dynamic equilibrium can be disturbed leading to enhanced ROS level and damage to cellular constituents which is called "oxidative stress, manifested as oxidative damage of lipids, proteins, and DNA (De Flora et al., 1994; Almroth et al., 2005; Tsangaris et al., 2011). Exposure of fish to metals may result in increases in reactive oxygen species (ROS) leading to impairment of normal oxidative metabolism and finally to oxidative stress (Lushchak, 2011). 
Water bodies receive increased number of agricultural and industrial chemicals which being taken up by organisms may perturb free radical processes. This is the case of the Bè lagoon located in Lomé, the capital of Togo and which is therefore exposed to high pollution (municipal, industrial and hospital waste, bank collapse). For many years, it has been subjected to multiple effluents discharges, without any previous treatment. This fact caused a progressive decline in the water quality, which is traduced in organic contamination and turbidity, the eutrophication and the pollution (Akpavi, 2002; Palou, 2009). Chemical analyses may not be sufficient to properly assess the adverse effects of the complex mixture of water contaminants (He et al., 2011). Thus, to assess the action of these on aquatic populations, a biomarker-based biomonitoring is a promising approach to provide early-warning signs of exposure (Zorita et al., 2007; Tlili et al., 2010). It therefore becomes crucial to have new methodological approaches that can detect signs of early biological effects. Then, this study aims to evaluate the concentrations of four heavy metals accumulated in various tissues of fishes (muscle, liver and gill) and the relationships between heavy metals and oxidative stress enzymes responses, as biomarkers of exposure (catalase activity and lipid peroxidation).

\section{MATERIALS AND METHODS \\ Materials \\ Biological materials}

The study involved a commercially viable fresh water fish Sarotherodon melanotheron (Rüppell) locally known as "Tilapia of lagoons". Fish weighed 100-150 g and their length was in the range of $25-35 \mathrm{~cm}$. Fish was netted with the help of local fishermen of the two selected ecosystems: Bè Lagoon located in Lomé (Capital of Togo) and the lake Togo, near the Hotel of the same name located about $30 \mathrm{~km}$ from Lomé in the town of Agbodrafo. 40 fishes were caught on each sites and returned alive to the laboratory in water trays. They were identified in the department of Animal Biology (University of Lomé). The livers, muscles and gills of the fishes were dissected out and divided in two lots. Ones were stored at $-4{ }^{\circ} \mathrm{C}$ in a deepfreezer for further enzymatic analysis when others were dried for heavy metals determination.

\section{Reagents}

32-mercaptoethanol, Triton X100, Bradford reagent, hydrogen peroxide, Tris$\mathrm{HCl}$, sodium dodecyl sulfate (SDS) and the solution of ethylene diamine tetra-acetic acid (EDTA) were provided by VWR International (Haasrod, Belgium). Nitric acid $\left(\mathrm{HNO}_{3}\right)$, thiobarbituric acid, hydrochloric acid $(\mathrm{HCl})$, malondialdehyde (MDA) and bovine serum albumin (BSA) were obtained from Sigma Chemicals (St. Louis, USA). The standard solutions of lead $(\mathrm{Pb})$, cadmium $(\mathrm{Cd})$, nickel $(\mathrm{Ni})$ and $(\mathrm{Cu})$ were provided by Merck KGaA (Darmstadt, Germany).

\section{Methods \\ Water collection}

Sampling was carried out at two stations selected (margin and middle) in Bè lagoon and Lake Togo to determine the heavy metals content of these two ecosystems. Five samples of $50 \mathrm{ml}$ were collected at each station in vials containing $2 \mathrm{ml}$ of concentrated $\mathrm{HNO}_{3}$ to avoid possible precipitation reactions and/or metal complexation.

\section{Mineralization of fish samples}

The fresh organs intended for metals determination were dried at $50{ }^{\circ} \mathrm{C}$ for $96 \mathrm{~h}$. Dry weights were determined before their reduction to powder by grinding in a mortar. 1 $\mathrm{g}$ of the powders obtained was added to $5 \mathrm{ml}$ of $\mathrm{HNO}_{3}(18 \mathrm{M})$ in a flask and placed on a heating device for the tissue digestion. The digestion mixtures were filtered and diluted up to $25 \mathrm{ml}$ with distilled water. The resulting solution is stored at room temperature until use.

\section{Preparation of post-mitochondrial supernatant (PMS)}

The fresh organs intended to enzymatic assays were washed three times in extraction 
buffer (10 mM Tris-HCl, $\quad \mathrm{pH} \quad 7.5)$ supplemented with EDTA (3.8 g/l), $\beta$ 2mercaptoethanol $(348 \mu \mathrm{l} / \mathrm{l})$ and Triton X100 (1 $\mathrm{ml} / \mathrm{l})$. Organs were then ground and homogenates obtained were added to $1 \mathrm{ml}$ of the buffer, centrifuged (13,000 g, $10 \mathrm{~min})$, and the supernatants separated from the pellets. The two fractions (supernatants and pellets) were stored at $-4{ }^{\circ} \mathrm{C}$ in a deep-freezer until use. The supernatants were used for protein assay and measurement of catalase activity while the MDA was assayed in the pellet.

\section{Dosage of heavy metals}

Metal quantification was performed using an atomic absorption spectrophotometer (AAS, Thermo Electron Corporation, Germany) with Flame Ionizing Detector (FID).We focused mainly on four metals (lead, cadmium, copper and nickel). Water withdrawals and digests obtained from the organs were filtered on Whatman filter paper and then analyzed by AAS. Merck standard solutions were used for calibration.

\section{Protein estimation}

Total protein concentrations in the liver, muscle and gill supernatants were evaluated according to the Bradford method (Bradford, 1976) at $595 \mathrm{~nm}$, using bovine albumin as the standard. Briefly, supernatants obtained in the extraction phase were diluted $(1 / 20 \mathrm{v} / \mathrm{v})$ with phosphate buffer $(100 \mathrm{mM}$, $\mathrm{pH}$ 7.8), homogenized, and $5 \mu \mathrm{l}$ of the mixtures or phosphate buffer alone were spread in triplicate in wells of a microplate. $250 \mu \mathrm{l}$ of Bradford reagent were then added to the contents of each well, incubated at room temperature for $30 \mathrm{~min}$ and the absorbance was measured at $595 \mathrm{~nm}$.

\section{Catalase activity (CAT activity) assay}

CAT activity was assayed according to the method of Aebi (1984) with minor modifications. Supernatants obtained previously after tissue extraction were diluted to $1 / 20 \mathrm{v} / \mathrm{v}$ in phosphate buffer $(100 \mathrm{mM}, \mathrm{pH}$ 7.8). Reaction mixtures containing $200 \mu \mathrm{l}$ of samples and $20 \mu \mathrm{l}$ of absolute ethanol were cooled for $30 \mathrm{~min}$ on ice, completed with 20 $\mu \mathrm{l}$ of Triton X100 and homogenized. Addition of $100 \mu \mathrm{H}_{2} \mathrm{O}_{2} \quad(0.66 \mathrm{M}$ in phosphate buffer $100 \mathrm{mM}, \mathrm{pH} 7.8)$ to $120 \mu \mathrm{l}$ of reaction mixture (sample) or supernatant alone (blank reaction) in multiwall plates trigger the reaction, and the consumption of $\mathrm{H}_{2} \mathrm{O}_{2}$ was measured by following the decrease of absorbance at $240 \mathrm{~nm}$ during 90 seconds. The constant $\mathrm{K}$ was determined by the formula: $\mathrm{K}$ $=2.3 / \Delta \mathrm{t} \times \log 10 \quad(\mathrm{DOzero} / \mathrm{DOt})$ where the minute is the unit of time and DOt is the absorbance measured at a time $t$ after reaction begins. CAT activity was then defined as the amount of enzyme that decompose $1 \mathrm{nmol}$ $\mathrm{H}_{2} \mathrm{O}_{2} /$ min at $25{ }^{\circ} \mathrm{C}$ and the results were expressed as enzyme unit (UCAT) per mg of protein.

\section{Lipid peroxidation (LPO) assay}

Lipid peroxidation was determined by measuring the thiobarbituric acid reactive substances (TBARS) as described previously by Satoh (1978) with minor modifications. The pellets obtained in the extraction phase were mixed with $200 \mu \mathrm{l}$ of extraction buffer (10 mM Tris-HCl, pH 7.4), homogenized, and $175 \mu \mathrm{l}$ of this mixture (sample) or N-methyl2-phenylindole $50 \mathrm{nM}$ (standard range) were introduced into $5 \mathrm{ml}$ tubes. The reaction mixture contained $250 \mu \mathrm{l}$ of $\mathrm{HCl} 1 \mathrm{M}, 100 \mu \mathrm{l}$ of SDS $9.8 \%, 1 \mathrm{ml}$ of thiobarbituric acid $0.67 \%$, and $330 \mu \mathrm{l}$ of distilled water. After homogenization, the tubes were incubated at $90{ }^{\circ} \mathrm{C}$ for $30 \mathrm{~min}$, cooled for $15 \mathrm{~min}$, diluted with $2.5 \mathrm{ml}$ of n-butanol before centrifugation (3000 g, $10 \mathrm{~min}$ ) and the absorbance measured in the supernatants at $532 \mathrm{~nm}$. TBARS levels were expressed as nmol MDA per $\mathrm{mg}$ of protein.

\section{Statistical analyzes}

Data have been expressed as mean \pm standard error of mean and analyzed with the software Graph Pad Prism 4. Differences between samples of the two sites were assessed using Student's two-tailed unpaired t-test. In all cases, the significance level adopted was $95 \%(\mathrm{P}<0.05)$. 


\section{RESULTS}

\section{Heavy Metal contents in water samples}

The AAS revealed the presence of lead $(\mathrm{Pb})$, cadmium $(\mathrm{Cd})$, nickel $(\mathrm{Ni})$ and copper $(\mathrm{Cu})$ in Bè lagoon at levels of $2.58 \pm 0.11$ $\mu \mathrm{g} / \mathrm{l}, 1.03 \pm 0.15 \mu \mathrm{g} / \mathrm{l}, 1.71 \pm 0.17 \mu \mathrm{g} / \mathrm{l}, 3.03 \pm$ $0.07 \mu \mathrm{g} / \mathrm{l}$ respectively. Only $\mathrm{Ni}$ and $\mathrm{Cu}$ were detected in water samples collected on the control site, Lake Togo, at concentrations of $1.54 \pm 0.22 \mu \mathrm{g} / \mathrm{l}$ and $0.89 \pm 0.18 \mu \mathrm{g} / \mathrm{l}$ respectively. The concentration of $\mathrm{Cu}$ in water samples of lake Togo was found significantly lower $(\mathrm{P}<0.0001)$ when compared with the polluted site (Table 1).

\section{Metal contents in the fish organs Lead $(\mathrm{Pb})$ content in fish organs}

The AAS didn't reveal the presence of $\mathrm{Pb}$ in tissues of fish collected from control site. In the fish samples of Bè lagoon, lead was found at the levels of $12.08 \pm 1.72 \mu \mathrm{g} / \mathrm{g}$ in the liver and $2.66 \pm 0.11 \mu \mathrm{g} / \mathrm{g}$ in the gill (Table 2).

\section{Cadmium (Cd) content in fish organs}

No traces of $\mathrm{Cd}$ were detected in organs of fish collected from the control site. In samples collected from Bè lagoon, this heavy metal was detected at levels of $6.96 \pm$ $0.26 \mu \mathrm{g} / \mathrm{g}$ in liver, $1.65 \pm 0.08 \mu \mathrm{g} / \mathrm{g}$ in muscle and $1.39 \pm 0.11 \mu \mathrm{g} / \mathrm{g}$ in gill (Table 3 ).

\section{Nickel (Ni) content in fish organs}

The concentration of $\mathrm{Ni}$ in the muscle of fishes collected from Bè lagoon was significantly higher than value from the control site. Values are respectively $3.41 \pm$ $0.13 \mu \mathrm{g} / \mathrm{g}(\mathrm{P}<0.0001)$ and $0.34 \pm 0.10 \mu \mathrm{g} / \mathrm{g}$. The concentration of $\mathrm{Ni}$ in livers from Bè lagoon was 22 time most higher than those from the control site (Table 4).

\section{Copper $(\mathrm{Cu})$ content in fish organs}

Table 5 shows levels of copper in tissues of fish sampled at two sites. Values of $\mathrm{Cu}$ in the liver, muscle and gill of fish of Bè lagoon $(43.04 \pm 3.28 \mu \mathrm{g} / \mathrm{g}, 10.47 \pm 1.34 \mu \mathrm{g} / \mathrm{g}$, $11.12 \pm 0.74 \mu \mathrm{g} / \mathrm{g}$ respectively) were observed to be significantly higher $(\mathrm{P}<0.0001)$ as compared with values of control site samples $(2.42 \pm 0.20 \mu \mathrm{g} / \mathrm{g}, \quad 0.40 \pm 0.01 \mu \mathrm{g} / \mathrm{g}$, $4.62 \pm 0.16 \mu \mathrm{g} / \mathrm{g}$ respectively).

\section{Biomarkers \\ Catalase activity}

The levels of catalase activity in liver $(50.43 \pm 5.72 \mathrm{UCAT} / \mathrm{mg})$ and in gill $(14.19 \pm 1.34 \mathrm{UCAT} / \mathrm{mg})$ of fish collected from Bè lagoon were found significantly higher $(\mathrm{P}<0.0001$ in liver and $\mathrm{P}<0.005$ in gill) when compared with values of control site samples $(13.70 \pm 1.36 \mathrm{UCAT} / \mathrm{mg}$ in liver and $1.72 \pm 0.39 \mathrm{UCAT} / \mathrm{mg}$ in gill) (Figure 1).

\section{Lipid peroxidation}

No significant difference was found between the pairs of values (Lake Togo and Bè lagoon) (Figure 2).

Table 1: Heavy metal concentrations in water samples at Lake Togo and Bè lagoon.

\begin{tabular}{lcc}
\hline Metals $(\boldsymbol{\mu g} / \mathbf{l})$ & Lake Togo & Bè lagoon \\
\hline Lead $(\mathrm{Pb})$ & $\mathrm{ND}$ & $2.58 \pm 0.11$ \\
Cadmium $(\mathrm{Cd})$ & $\mathrm{ND}$ & $1.03 \pm 0.15$ \\
Nickel $(\mathrm{Ni})$ & $1.54 \pm 0.22$ & $1.71 \pm 0.17$ \\
Copper $(\mathrm{Cu})$ & $0.89 \pm 0.18$ & $3.03 \pm 0.07 * * *$ \\
\hline
\end{tabular}

Values are expressed as means \pm SEM $(n=5)$. ***P $<0.0001$ when compared with values of control site (lake Togo). The contents of water samples are expressed as $\mu \mathrm{g} / 1$ (ND = not detected. 
Table 2: Lead $(\mathrm{Pb})$ accumulated in fish organs.

\begin{tabular}{lccc}
\hline Metals & Liver & Muscle & Gill \\
\hline $\mathrm{Pb}(\mu \mathrm{g} / \mathrm{g})$ & & & \\
Lake Togo & $\mathrm{ND}$ & $\mathrm{ND}$ & $\mathrm{ND}$ \\
Bè lagoon & $12.08 \pm 1.72$ & $\mathrm{ND}$ & $2.66 \pm 0.11$ \\
$\%$ of difference & - & - & - \\
\hline \multicolumn{2}{l}{ Values are expressed as means \pm SEM $(\mathrm{n}=5)$. The contents of fish organs are expressed as } \\
$\mu \mathrm{g} / \mathrm{g}$ of dry weight $(\mathrm{ND}=$ not detected $)$.
\end{tabular}

Table 3: Cadmium (Cd) accumulated in fish organs.

\begin{tabular}{lccc}
\hline Metals & Liver & Muscle & Gill \\
\hline Cd $(\boldsymbol{\mu g} / \mathbf{g})$ & & & ND \\
\hline Lake Togo & ND & ND & $1.39 \pm 0.11$ \\
\hline Bè lagoon & $6.96 \pm 0.26$ & - & - \\
\hline$\%$ of difference & - & $1.65 \pm 0.08$ & \\
\hline $\begin{array}{l}\text { Values are expressed as means } \pm \text { SEM }(\mathrm{n}=5) \text {. The contents of fish organs are expressed as } \mu \mathrm{g} / \mathrm{g} \text { of dry weight }(\mathrm{ND}=\text { not } \\
\text { detected). }\end{array}$
\end{tabular}

Table 4: Nickel (Ni) accumulated in fish organs.

\begin{tabular}{lccc}
\hline Metals & Liver & Muscle & Gill \\
\hline $\mathbf{N i}(\boldsymbol{\mu g} / \mathbf{g})$ & \multicolumn{3}{l}{} \\
\hline Lake Togo & $6.23 \pm 0.65$ & $0.34 \pm 0.10$ & $0.54 \pm 0.05$ \\
Bè lagoon & $7.57 \pm 0.60$ & $3.41 \pm 0.13^{* * *}$ & $1.54 \pm 0.23 * *$ \\
$\%$ of difference & 22 & 903 & 185 \\
\hline Values are expressed as means \pm SEM $(\mathrm{n}=5)$. $* * \mathrm{P}<0.005$ and $* * * \mathrm{P}<0.0001$ when compared with values of control site \\
(lake Togo). The contents of fish organs are expressed as $\mu \mathrm{g} / \mathrm{g}$ of dry weight $(\mathrm{ND}=$ not detected).
\end{tabular}

Table 5: Copper $(\mathrm{Cu})$ accumulated in fish organs.

\begin{tabular}{lccc}
\hline Metals & Liver & Muscle & Gill \\
\hline Cu $(\boldsymbol{\mu g} / \mathbf{g})$ & & & \\
Lake Togo & $2.42 \pm 0.20$ & $0.40 \pm 0.01$ & $4.62 \pm 0.16$ \\
Bè lagoon & $43.04 \pm 3.28 * * *$ & $10.47 \pm 1.34 * * *$ & $11.12 \pm 0.74 * * *$ \\
$\%$ of difference & 1679 & 2518 & 141 \\
\hline $\begin{array}{l}\text { Values are expressed as means } \pm \text { SEM }(\mathrm{n}=5) \text {. } * * * \mathrm{P}<0.0001 \\
\text { contents of fish organs are expressed as } \mu \mathrm{g} / \mathrm{g} \text { of dry weight. }\end{array}$
\end{tabular}




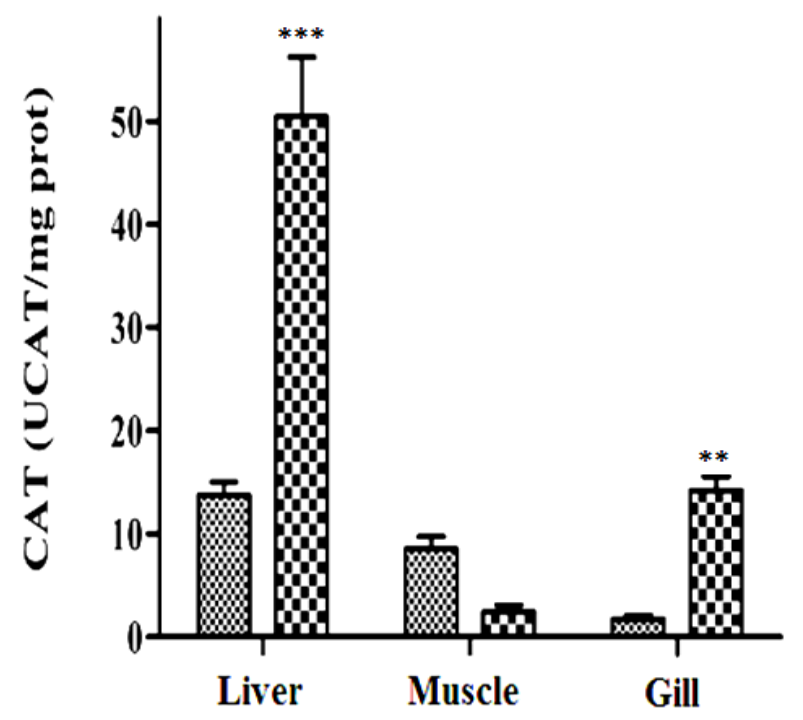

aㅐ Lac Togo

$\mathbf{m i d}$ Bè lagoon

Figure 1: The kinetics of the decomposition of hydrogen peroxide by catalase in liver, muscle and gill of fish Sarotherodon melanotheron was followed at $240 \mathrm{~nm}$ using a microplate reader. The results are expressed in units of catalase (UCAT) / mg of protein (means \pm SEM). Significant differences $* * \mathrm{P}<0.005$ in gill and $* * * \mathrm{P}<0.0001$ in liver were observed when values at two sites were compared.

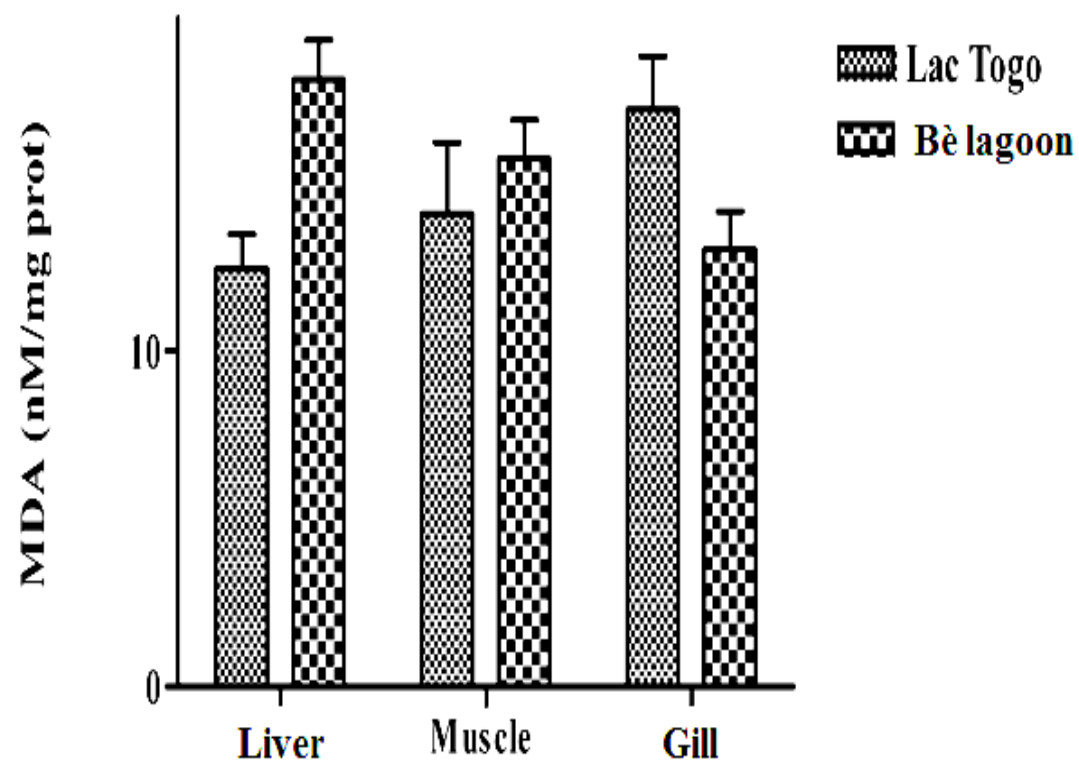

Figure 2: The reaction between the products of lipid peroxidation (MDA) and thiobarbituric acid product complexes TBARS which absorbance is measured at $595 \mathrm{~nm}$ using a microplate reader. The results are expressed as nanomoles of MDA/mg of protein. No significant difference was found between the pairs of values. 


\section{DISCUSSION}

Different metals concentrations were found in samples of the two sites chosen for this study. Bè lagoon showed the highest concentrations of the four metals $(\mathrm{Pb}, \mathrm{Cd}, \mathrm{Ni}$ and $\mathrm{Cu}$ ). The presence of these compounds in the environment could result from several factors. The most important are human activities that generate all kinds of wastes (domestic, agricultural, hospital and industrial). As Bè lagoon is located in the capital, it's likely the most polluted environment.

Often located downstream of food chains, aquatic species in general and especially fish are directly exposed to pollutants. The result is usually the accumulation of these pollutants in fish's tissues (Girault et al., 1998, Lopez et al., 2001; Dautremepuits et al., 2004) as showed by AAS analysis. The highest concentrations were found in fish samples of Bè lagoon with percentages of difference between sites ranging from 22 to 2518 . Indeed, the transfer of pollutants derived from the environment to the fish is even easier that these organisms have large areas of exchange with their environment (gill epithelium, gut wall, coating integumentary) involved in functions as respiration, nutrition or excretion (Anandraj et al., 2002). Fish is then an excellent bioindicator of environmental pollution and therefore can be used for the assessment of the quality of aquatic environment (Farombi et al., 2008; Oliveira et al., 2010). However, the presence of metals in tissues is due to the phenomenon of bioaccumulation (Ramade, 1992). Bioaccumulation is the direct increase in the concentration of a contaminant as it passes from water to aquatic organisms (bioconcentration) and from an organism to another one through the food chain (bioamplification) (Ribeyre and Boudou, 1989; Ramade, 1992). Moreover, among the organs sampled, liver appears to be the most contaminated. This observation is not surprising given its importance in the process of detoxification and elimination of xenobiotic.

Many studies conducted during recent years show that heavy metals accumulation may lead to oxidative stress, with an overproduction of ROS that can address various organic molecules such as nucleic acids, proteins and membrane lipids (Oliva et al., 2012). Among the four heavy metals targeted, $\mathrm{Pb}$ and $\mathrm{Cd}$ are essentially deleterious, with no positive properties known in organisms. Wang et al., (2004) studies indicate that $\mathrm{Cd}$ inhibits the electron transfer chain and causes superoxide radical formation, which lead to hydrogen peroxide increase. $\mathrm{Ni}$ and $\mathrm{Cu}$ are heavy metals with ambiguous roles in biological systems. On one hand they are important as cofactors for a wide range of proteins and enzymes in all organisms, and they are therefore regarded as micronutrients (Stohs and Bagchi, 1995). Cu is an essential element, acting at low concentrations as a cofactor for important enzymes (Franco et al., 2009). On the other hand, $\mathrm{Cu}^{2+}$ ions can be reduced by thiol compounds to $\mathrm{Cu}^{+}$, which promotes the formation of $\mathrm{OH} \bullet$ through the decomposition of $\mathrm{H}_{2} \mathrm{O}_{2}$ via Fenton reaction, leading finally to adverse effects (Pytharopoulou et al., 2011).

Our results showed an increase in catalase activity in all organ samples at both sites with a higher expression level in Bè lagoon. This result, as demonstrated also by Hansen et al. (2006) and Farombi et al. (2008), suggests that prolonged exposure of an organism to some pollutants can lead to the proliferation of peroxisomes (organelles containing catalase), thus contributing to the increase in catalase activity observed in organisms of the Bè Lagoon. Similarly, the MDA levels measured are relatively high even though no significant difference was observed between samples collected at both sites. All these results indicate that in Bè lagoon, fish are subjected to oxidative stress. However, it seems that organisms of this ecosystem have developed adaptive strategies, protecting them 
against some deleterious effects like lipid peroxidation which outcomes can be fatal.

\section{Conclusion}

It appears from the results presented in this paper that Bè lagoon is a polluted ecosystem. Similarly, heavy metals are present at various levels in different organs in fish at this site where they induce a state of oxidative stress resulting in an increase in catalase activity. Of all the organs studied, the liver is the one with the highest levels of metals and enzyme activity. Radical attack of membrane lipids has also been demonstrated by measurement of a product of lipid peroxidation: MDA. However the lack of significant difference between MDA levels measured in the organs of fishes collected in Bè lagoon and Lake Togo (control site) suggests an effective defense system against free radicals, and therefore an adaptation of these organisms to their environment. However, confirmation of this hypothesis requires further seasonal ecotoxicological studies turning on the evaluation of several markers of oxidative stress including superoxide dismutase activity (SOD) and glutathione peroxidase (GPx) on the one hand, reproductive capacity and development of fish on the other hand. In addition, consumption of animals taken from Bè lagoon may therefore more or less long term be detrimental to populations.

\section{ACKNOWLEDGEMENTS}

The authors are grateful to Georges APETOGBO for skillful assistance in analyses and Edouard Tetegah for constructive comments on the manuscript.

\section{REFERENCES}

Aebi H. 1984. Catalase in vitro. Method. Enzymol., 105: 121-126.

Akpavi S. 2002. Distibution et écologie d'Echornia Crassipes (Pontederiaceae) et Pistia Stratiotes (Araceae) dans la région Maritime Est du Togo. Mémoire de DEA,Université de Lomé, Lomé, p.72.
Almroth BC, Sturve J, Berglund A, Forlin L. 2005. Oxidative damage in eelpout (Zoarces viviparus), measured as protein carbonyls and TBARS, as biomarkers. Aquat.Toxicol., 73: 171-180.

Anandraj A, Marshall DJ, Gregory A, McClurg TP. 2002. "Metal accumulation, filtration and $\mathrm{O}_{2}$ uptake rates in the mussel Perna pernaexposedto $\mathrm{Hg}^{2+}, \mathrm{Cu}^{2+}$ and $\mathrm{Zn}^{2+"}$. Comp. Biochem. Physiol Part C: Toxicol. \&Pharmacol., 132: 355-363.

Bradford M. 1976. A rapid and sensitive method for the quantitation of microgram quantities of protein utilizing the principle of protein dye-binding. Anal. Biochem., 72: 248-254.

Collén J, Pinto E, Pedersén M, Colepicolo P. 2003. Induction of oxidative stress in the red macro algae Gracillaria tenuistipitata by pollutant metals. Arch. Environ. Contam. Toxicol., 45: 337-342.

Dautremepuits C, Paris-Palacios S, Betoulle S, Vernet G. 2004. Modulation in hepatic and head kidney parameters of carp (Cyprinus carpio L.) induced by copper and chitosan. Comp. Biochem. Physiol., 137: 325-333.

De Flora S, Bennicelli C, Bagnasco M. 1994. Genotoxicity of mercury compounds. A review. Mutat. Res., 317: 57-79.

Farombi E, Ajimoko R, Adelowo A. 2008. Effect of Butachlor on antioxidant enzyme status and lipid peroxidation in fresh water African catfish, (Clarias gariepinus). Int. J. Environ. Res. Public Health., 5(5): 423-427.

Franco R, Sánchez-Olea R, Reyes-Reyes M, Panayiotidis I. 2009. Environmental toxicity, oxidative stress and apoptosis: Ménage à Trois. Mutat. Res., 674: 3-22.

Girault L, Boudou A, Dufourc EJ. 1998. 113Cd, 31P-NMR and fluorescence polarization studies of cadmium (II) interactions with phospholipids in model membranes. Biochim. Biophys. Acta., 1414:140-154.

Hansen B, Romma S, Garmo A, Olsvik P, Andersen R. 2006. Antioxidative stress proteins and their gene expression in 
brown trout (Salmotrutta) from three rivers with different heavy metal levels. Comp. Biochem. Physiol. C., 7: 9-24.

He X, Nie X, Wang Z, Cheng Z, Li K, Li G, Wong M, Liang X, Tsui T. 2011. Assessment of typical pollutants in waterborne by combining active biomonitoring and integrated biomarkers response. Chemosphere, 84: 1422-1431.

Lopes P, Pinheiro T, Santos M, da Luz Mathias M, Collares-Pereira M. 2001. Response of antioxidant enzymes in freshwater fish populations (Leuciscus alburnoides complex) to inorganic pollutants exposure. Sci. Tot. Environ., 280 : 153-163.

Lushchak V. 2011. Environmentally induced oxidative stress in aquatic animals. Aquat. Toxicol., 101: 13-30.

Oliva M, Vicente J, Gravato C, Guilhermino L, Galindo-Riano D. 2012. Oxidative stress biomarkers in Senegal sole, Solea senegalensis, to assess the impact of heavy metal pollution in a Huelva estuary (SW Spain): Seasonal and spatiall variation. Ecotoxicol. Environ. Saf., 75: $151-162$.

Oliveira M, Ahmad I, Maria VL, Pacheco M, Santos M. 2010. Monitoring pollution of coastal lagoon using Liza aurata kidney oxidative stress and genetic endpoints: an integrated biomarker approach. Ecotoxicology, 19: 643-653.

Palou SK. 2009. Caracterisation physicochimique des sediments de dragage du lac est de la lagune de Lomé. Mémoire de DUIT, Université de Lomé, Lomé.

Pereira P, Pablo H, Rosa-Santos F, Pacheco M, Vale C. 2009. Metal accumulation and oxidative stress in Ulva sp. substantiated by response integration into a general stress index. Aquat. Toxicol., 91: 336345.

Phillips JH, Rainbow P. 1994. Biomonitoring of Trace Aquatic Contaminants. Aldenn Press Ltd: Oxford.
Pytharopoulou S, Grintzalis K, Sazakli E, Leotsinidis E, Georgiou C, Kalpaxis L. 2011. Translational responses and oxidative stress of mussels experimentally exposed to $\mathrm{Hg}, \mathrm{Cu}$ and $\mathrm{Cd}$ : One pattern does not fit at all. Aquat.Toxicol., 105 : 157- 165.

Ramade F. 1992. Précis d'écotoxicologie. In Collection d'Ecologie 22. Edition Masson: Paris; 293p.

Ribeyre F, Boudou A. 1989. Trophic chains and experimental ecosystems : study of bioaccumulation and transfer processes. Aqua. Ecotoxicol., 1: 3-46.

Satoh K. 1978. Serum lipid peroxide in cerebrovascular disorders determined by a new colorimetric method. $\mathrm{Cl}$. Chim. A., 90: $37-43$.

Stohs SJ, Bagchi D. 1995. Oxidative mechanisms in the toxicity of metal ions. Free Radic. Biol. 18: 321-336.

Tlili S, Jebali J, Banni M, Haouas Z, Mlayah A, Helal A, Boussetta H. 2010. Multimarker approach analysis in common carp Cyprinus carpio sampled from three freshwater sites. Environ. Monit. Assess, 168: 285-298.

Tsangaris C, Vergolyas M, Fountoulaki E, Nizheradze K. 2011. Oxidative stress and genotoxicity biomarker responses in grey mullet (Mugil cephalus) from a polluted environment in Saronikos gulf, Greece. Arch. Environ. Contam. Toxicol., 61: 482-490.

Wang Y, Fang J, Leonard SS, Rao K. 2004. Cadmium inhibits the electron transfert chain and induces reactive oxygen species. Free Radic. Biol. Med., 36: 1434-1443.

Zorita I, Apraiz I, Ortiz-Zarragoitia M, Orbea A, Cancio I, Soto M, Marigomez I, Cajaraville M. 2007. Assessment of biological effects of environmental pollution along the NW Mediterranean Sea using mussels as sentinel organisms. Environ. Pollut., 148: 236-250. 